J. Clin. Chem. Clin. Biochem.

Vol. 15,1977 , pp. 607-614

\title{
Characterization of Leucocyte Alkaline Phosphatase in Normal Subjects and under Different Physiological and Pathological Conditions
}

By Abdelbaset Anwer El-Aaser

Cell Chemistry Unit, Cancer Institute, Cairo University,

Faiza Hammouda

Department of Clinical Pathology, Cancer Institute, Cairo University,

Olfat Mohieddin

Department of Clinical Pathology, Faculty of Medicine, Cairo University

and

Dalal Salem Hindawy

Department of Clinical Pathology, Cancer Institute, Cairo University

(Received January 26/June 6, 1977)

Summary: Leucocyte alkaline phosphatase activity was determined in both cell homogenates and cell extracts. Leucocytes were obtained from normal controls, pregnant females, and patients with various haematological disorders.

Enzyme activity presented in terms of $\mu \mathrm{mol}$ phosphorus per minute per $10^{8}$ neutrophils was more in agreement with the reported cytochemical data in both normal and pathological cases, than the values expressed in terms of $\mu \mathrm{mol}$ phosphorus per minute per $10^{8}$ leucocytes or per protein. This was explained by the possible low enzyme activity of lymphocytes included in the latter. Cases of acute and chronic granulocytic leukaemias showed very low activity compared to normal, irrespective of the method of presentation of activity.

Characterization of leucocyte alkaline phosphatase isoenzyme in normal subjects, using substrate specificities and selective inhibition tests, showed that it is largely similar to that of liver, bone, kidney and spleen, but differs markedly from those of the intestine and placenta. In this respect, the leucocyte alkaline phosphatase in pathological cases showed no variation from normal, except in cases of acute and chronic granulocytic leukaemias and pregnancy, where the leucocyte alkaline phosphatase enzyme showed a tendency to be heat resistant. In addition, the enzyme from acute granulocytic leukaemia cases showed a higher affinity for $\alpha$-naphthylphosphate, $o$-carboxyphenylphosphate, and adenosine $5^{\prime}$-monophosphate.

Charakterisierung der alkalischen Phosphatase von Leukocyten bei Normalpersonen und unter verschiedenen physiologischen und pathologischen Bedingungen

Zusammenfassung: Die Aktivịạ̈t der alkalischen Phosphatașe von Leukocyten wurde in Zellhomogenaten und Zellextrakten untersucht. Die Leukocyten stammten von normalen Kontrollpersonen, Schwangeren und Patienten mit verschiedenen hämatologischen Störungen.

Der Bezug der Enzymaktivität als freigesetztes Phosphat in $\mu \mathrm{mol} / \mathrm{min}$ auf $10^{8}$ Neutrophile stimmte in normalen und pathologischen Fällen besser mit den berichteten cytochemischen Daten überein als die Angabe in $\mu \mathrm{mol} / \mathrm{min} \cdot 10^{8}$ Leukocyten oder in $\mu \mathrm{mol} / \mathrm{min} \cdot \mathrm{g}$ Protein. Dies wird auf die möglicherweise geringe Enzymaktivität der Lymphocyten erklärt. Fälle von akuter und chronischer granulocytärer Leukämie zeigten - welche Bezugsgröße auch gewählt wurde -, verglichen mit Normalpersonen, eine sehr geringe Aktivität. 
Die Charakterisierung der Isoenzyme der alkalischen Phosphatase von Normalpersonen wurde anhand von Substratspezifitäten und selektiven Hemmtests durchgeführt und zeigte, daß das Spektrum in hohem Maße der Gruppe von Leber-, Knochen-, Urin- und Milz-Isoenzymen ähnlich, jedoch von der von Darm und Placenta deutlich unterschiedlich ist. Die alkalische Phosphatase von Leukocyten zeigte in dieser Hinsicht in pathologischen Fällen keinen Unterschied zu Normalpersonen, jedoch zeigte die alkalische Phosphatase in Fällen von akuter und chronischer granulocytotischer Leukämie und in der Schwangerschaft eine Tendenz zur Hitzeresiștenz. Außerdem zeigte sich bei Fällen von akuter granulocytotischer Leukämie eine höhere Affinität gegenüber $\alpha$-Naphthylphosphat, $o$-Carboxyphenylphosphat und AMP.

\section{Introduction}

The clinical usefulness of leucocyte alkaline phosphatase determinations has been widely studied. Thus, a decreased enzyme activity was found in patients with chronic granulocytic leukaemia $(1,2)$. Elevations of enzyme activity have been reported in several diseased conditions associated with reactive leucocytosis of the granulocytic type (2).

The possible heterogeneity of human leucocyte alkaline phosphatase was documented by Trubowitz et al (3) in studies of the magnesium ion and zinc ion requirements of the enzyme. Isoenzymes of leucocyte alkaline phosphatase have been demonstrated by several techniques, using starch gel electrophoresis (4-7) and agar gel electrophoresis (8). However, confusing results have been found in the literature, concerning the normal patterns of these isoenzymes $(4,7,9)$.

The aim of the present work is, firstly, to show in what respect leucocyte alkaline phosphatase is similar to organ alkaline phosphatase isoenzymes. Secondly, to find out whether the enzyme in physiological and pathological conditions differs from that of normal subjects.

\section{Materials and Methods}

\section{Selection of cases}

The material studied in this work was obtained from 28 normal controls within the age range of 5-70 years (blood bank donors, laboratory staff or their relatives), 6 pregnant females (physiological leucocytosis), and 119 patients with various haematologic disorders presenting to the Cancer Institute outpatient clinic. In each case, the diagnosis was initially established on clinical findings, peripheral blood and bone marrow examination. Biopsy from the affected organs was resorted to in the diagnosis of lymphomas and solid tumours. All the cases were subjected to the present study before receiving any kind of treatment.

\section{Preparation of leucocytes}

The separation of leucocytes was carried out according to Peacock et al (10) with slight modification. The leucocyte preparation was freed of most contaminating erythrocytes by exposure to hypotonic saline (6). Total and differential white cell counts were performed in cell preparation to determine the percentage of mature granulocytes.

Purified preparations of leucocyte alkaline phosphatase enzyme

Enzyme extraction from leucocytes was carried out by $n$ butanol according to Bottomley et al (11). 8-10 mi leucocyte cell preparation with a known total and differential white cell count preparêd ás abovie were used for this purpose. The clear aqueous layer which contains all the enzyme activity was stored at $-20^{\circ} \mathrm{C}$ for biochemical analysis.

Preparation of purified alkaline phosphatase enzyme from liver, bone, kidney, spleen, placenta, and intestine was performed using $n$-butanol, as described above for leucocyte alkaline phosphatase. The organs were obtained from postmortem patients immediately after death. The placentà was taken from full term pregnant females soon after delivery.

\section{Enzyme assay}

The leucocyte alkaline phosphatase activity was estimated by two techniques. In the first method, $\beta$-glycerophosphate was utilized as a substrate, and the liberated phosphorus was estimated colorimetrically at $640 \mathrm{~nm}$ according to Fiske \& Subbarow (12). The second method is based on determining the amount of yellow colour of $p$-nitrophenol that is liberated from the colourless $p$-nitrophenylphosphate. The reaction was stopped by adding $2.5 \mathrm{ml}$ of $0.05 \mathrm{~mol} / 1 \mathrm{NaOH}$, and the colour was read at $410 \mathrm{~nm}$. The incubation medium of total volume of $0.5 \mathrm{ml}$ consisted of tris-buffer $\mathrm{pH} 9.5,200 \mathrm{mmol} / \mathrm{l}$, substrate. $10 \mathrm{mmol} / 1$, and $\mathrm{MgCl}_{2} 5 \mathrm{mmol} / 1$. The readings were compared with those obtained from standard phosphorus and $p$-nitrophenol on calibrated curves. The enzyme activity was calculated either as $\mu \mathrm{mol}$ or $\mathrm{mg}$ phosphorus or $p$-nitrophenol released per $10^{8}$ leucocytes, or per $10^{8}$ neutrophils, or per gram protein.

The protein content of the cell homogenate, cell extract, and plasma was estimated by the biuret method of Gormall et al (13).

\section{Results}

The levels of leucocyte alkaline phosphatase activity in normal physiological, and pathological conditions, using $\beta$-glycerophosphate as a substrate are shown in table 1 . In all cases investigated, the mean values for the enzyme activity of purified preparations were, on average, 1.6 times (range 1.4-1.9) higher than that of cell homogenate, when the activity was expressed as per $10^{8}$ leucocytes or $10^{8}$ neutrophils, whereas it was 7 times higher when represented per gram protein of leucocytes.

In all types of acute or chronic leukaemias and lymphosarcoma the enzyme activity expressed either as per $10^{8}$ leucocytes or gram protein of leucocytes showed a remarkable decrease from the normal values (ranging from 43-98\%), while they showed a highly significant increase above the normal level (range 48-157\%) when activity was expressed as per $10^{8}$ neutrophils, except in the case of acute and chronic granulocytic leukaemias, which still showed values that were $8-18 \%$ of nörmal. Cases of myelosclerosis, Hodgkin's disease, and other malignancies of a non-haemopoietic nature (such as lung, 


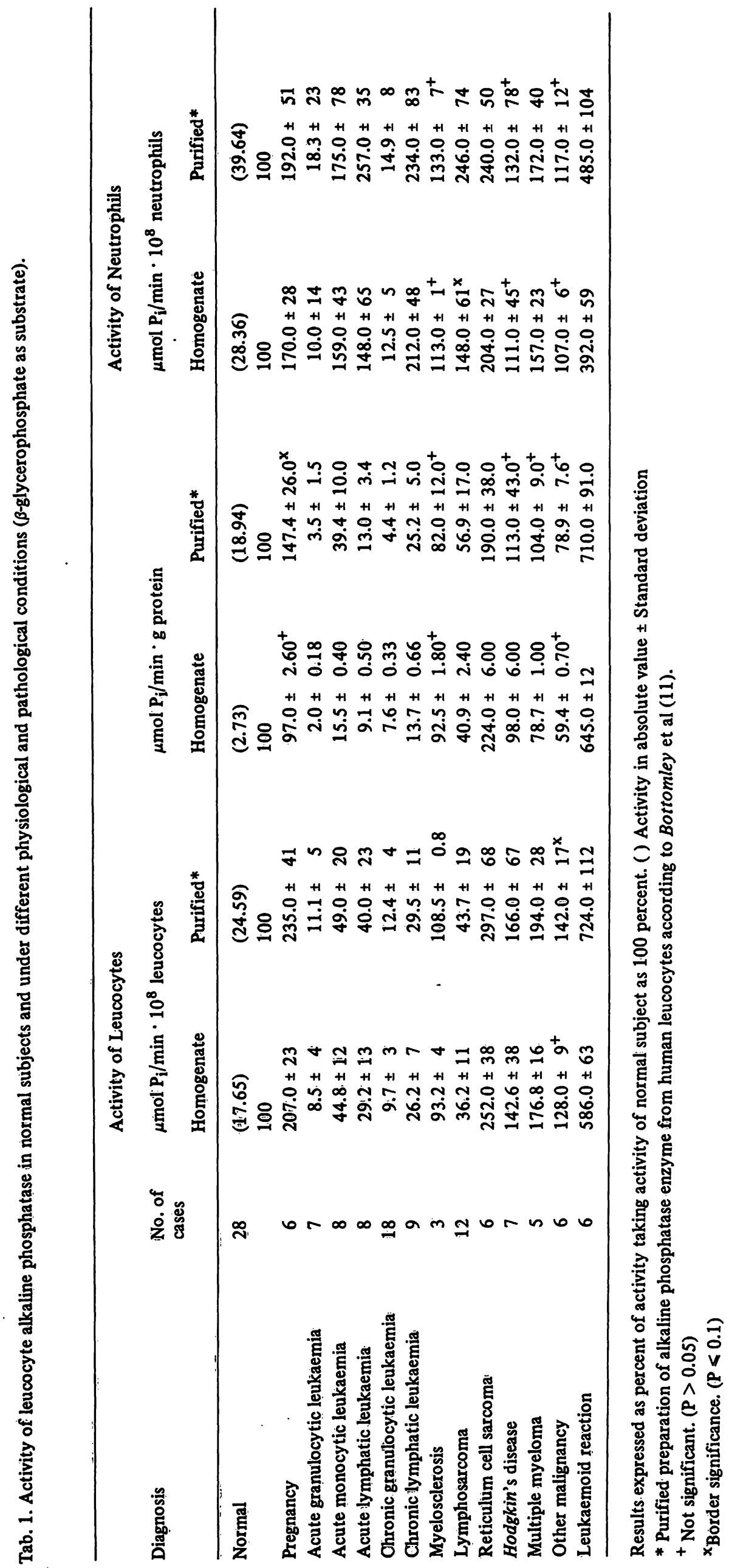


breast, bladder) showed no significant changes from that of normal level. On the other hand, reticulum cell sarcoma, leukaemoid reaction, and pregnancy showed very highly significant increases from 47 to $624 \%$ above the normal values, irrespective of the method of expressing the activity. Multiple myeloma showed a significant increase when the activity was expressed as per $10^{8}$ leucocytes or per $10^{8}$ neutrophils (57-94\%), and a $20 \%$ decrease, or no change, when the activity was expressed per gram protein of leucocytes.

Comparative studies of specific activities of alkaline phosphatase in plasma and purified enzyme preparation of leucocytes, of normal and different physiological and pathological conditions were carried out using $\beta$-glycerophosphate and $p$-nitrophenylphosphate as substrates. It was found that the rate of hydrolysis of $p$-nitrophenylphosphate by the plasma alkaline phosphatase was twice that of $\beta$-glycerophosphate ( $\beta$-glycerophosphate to $p$-nitrophenylphosphate ratio equals 0.54 ) in normal and all other conditions, except in pregnancy, when the activity ratio of $\beta$-glycerophosphate to $p$-nitrophenylphosphate was equal to 1.36 . In all the pathological cases investigated the enzyme level of the plasma was the same as that in normal individuals, while in pregnancy, the plasma enzyme increased by $360 \%$ above normal using $\beta$-glycerophosphate as substrate. On the other hand, the alkaline phosphatase activity in the purified enzyme preparation of leucocytes showed equal affinity to both $\beta$-glycerophosphate and $p$-nitrophenylphosphate, in both normal and other conditions, except in pregnancy, where the enzyme showed a lower affinity for $p$-nitrophenylphosphate ( $\beta$-glycerophosphate to $p$-nitrophenylphosphate ratio equals 0.84 ). Characterization of the alkaline phosphatase isoenzyme of different organ tissues and leucocytes was carried out with respect to substrate specificities and selective inhibition. Table 2 presents the results obtained with different substrates comparing a purified preparation of normal leucocyte alkaline phosphatase with tissue alkaline phosphatase from liver, kidney, bone, spleen, intestine, and placenta. Taking the activity with $\beta$ glycerophosphate as $100 \%$, the leucocyte alkaline phosphatase from normal subjects catalyses the hydrolysis of $p$-nitrophenylphosphate and $\alpha$-naphthylphosphate equally, but the activity is slightly less than with $\beta$ glycerophosphate (about $15 \%$ less), while with 0 carboxyphenylphosphate and adenosine- 5 'monophosphate the rate of hydrolysis was less than that of $\beta$-glycerophosphate by 50 and $32 \%$ respectively. This was in agreement with the values obtained with liver, kidney, bone, and spleen isoenzymes, and differs from that of intestinal and placental isoenzymes. The latter showed a higher affinity for $O$-carboxyphenylphosphate and adenosine- 5 'monophosphate than for $\beta$-glycerophosphate by 19 and $40 \%$ respectively, while with $p$-nitrophenylphosphate and $\alpha$-naphthylphosphate the activity was less than that observed with $\beta$-glycerophosphate by about $50 \%$.
Comparison between normal leucocyte alkaline phosphatase and that in different physiological and pathological conditions with respect to substrate specificities is represented in table 3 . No significant differences were observed between the enzyme activities from acute or chronic leukaemias, lymphomas and normal persons, except in the case of acute granulocytic leukaemia which showed an activity significantly higher than normal when $\alpha$-naphthylphosphate, 0 -carboxyphenylphosphate and adenosine- $5^{\prime}$-monophosphate were used $(P \leqslant 0.05)$. In pregnancy and leukaemoid conditions, there was a higher affinity to both $p$-nitrophenylphosphate and $\alpha$-naphthylphosphate $(\mathrm{P} \leqslant 0.005, \mathrm{P} \leqslant 0.05$ respectively).

Table 2 shows the results of selective inhibition using $L$-phenylalanine, taurocholate, urea, zinc ions, cysteine, and heating at $56^{\circ} \mathrm{C}(30 \mathrm{~min}$ at $\mathrm{pH} 7.0)$. The.normal leucocyte inhibitory pattern was similar to that obtained from purified enzyme preparation of liver, kidney, bone, and spleen isoenzymes, but remarkably different from that of intestinal and placental isoenzymes. The latter two isoenzymes showed marked resistance to heat treatment, and sensitivity to inhibition by $L$ phenylalanine, but not by taurocholate.

There was no significant difference in the behaviour of normal leucocyte alkaline phosphatase and that of leukaemias towards the above-mentioned treatments; with the exception of acute and chronic granulocytic leukaemias which behaved differently from normal with respect to heat treatment and inhibition by cysteine. The latter were found to be heat resistant and more sensitive to inhibition by cysteine, thus resembling the leucocyte alkaline phosphatase in pregnancy (tab. 3).

\section{Discussion}

Analysis of the biochemical data obtained from the present study showed that the enzyme activity represented in terms of $\mu \mathrm{mol}$ phosphorus per minute per $10^{8}$ neutrophils was more in agreement with the reported cytochemical data in both normal and pathological cases, than that expressed in terms of $\mu \mathrm{mol}$ phosphorus per minute per $10^{8}$ leucocytes (14-15). This may be due to the low enzyme activity of lymphocytes included in the latter calculation.

Cytochemical studies showed no or very low enzyme activity in lymphocytes (14-18). Park (17) reported the presence of two leucocyte alkaline phosphatase isoenzymes; one is located in neutrophils and catalyses the hydrolysis of $\beta$-glycerophosphate and $p$-nitrophenylphosphate equally; the other is present in lymphocytes and catalyses the hydrolysis of $\beta$ glycerophosphate only. However, in the present study, the leucocyte alkaline phosphatase of the purified preparation catalysed the hydrolysis of $\beta$-glycerophosphate and $p$-nitrophenylphosphate nearly equally. Attempts to characterize the leucocyte alkaline phosphatase isoenzyme in normal leucocytes, showed that 


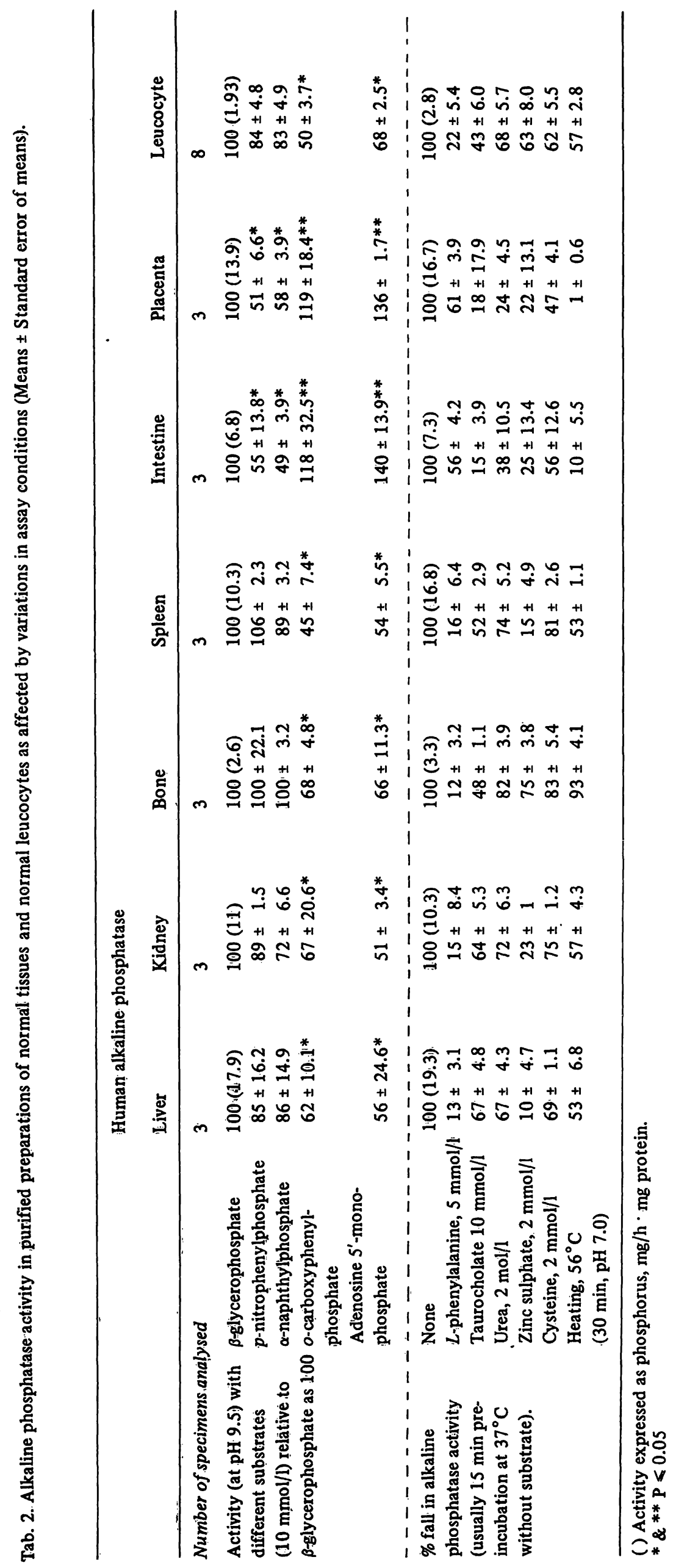




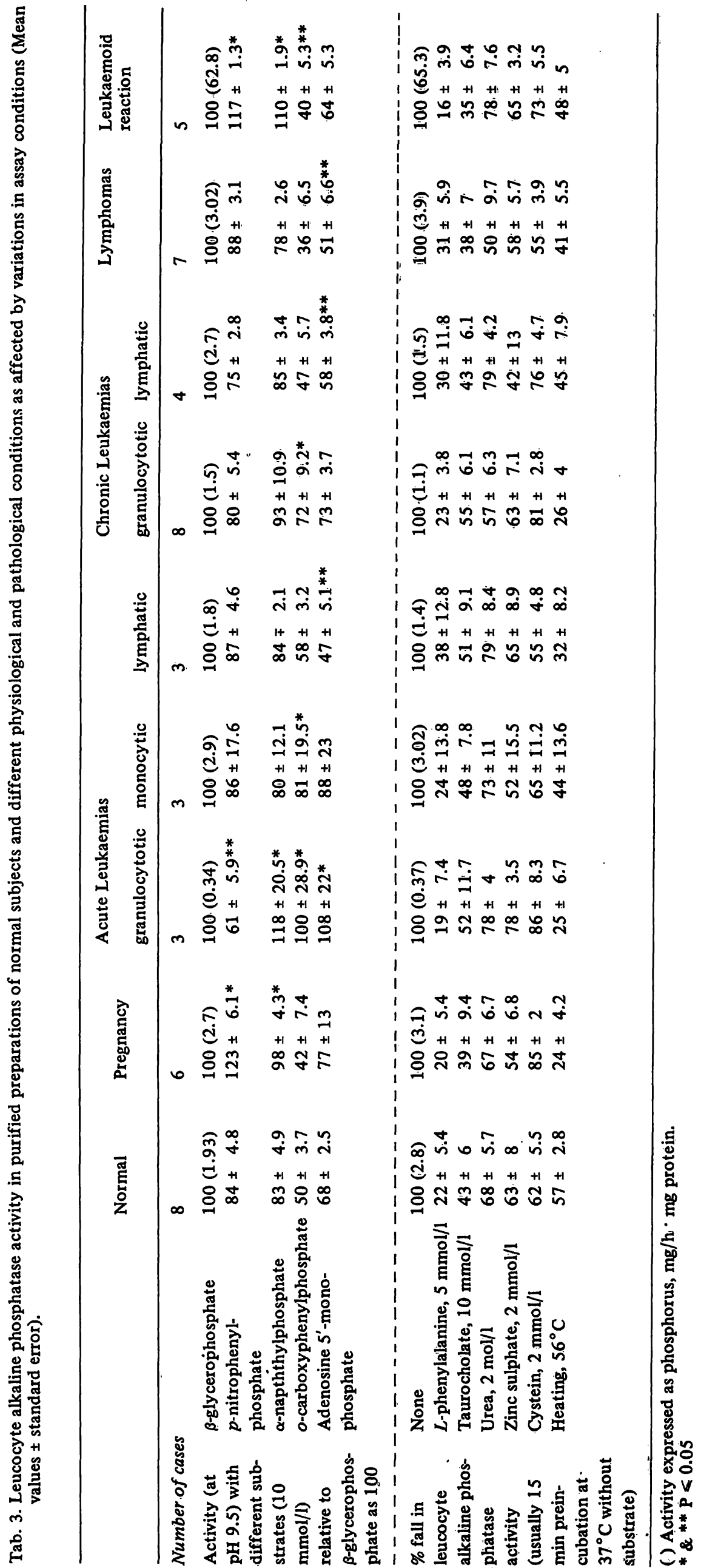


it is largely similar to the group of liver, bone, kidney, and spleen isoenzymes, but markedly differs from the intestinal or placental ones (Table 2). This was in respect to substrate specificities and selective inhibition.

Leucocy te alkaline phosphatase of lymphomas and leukaemias was similar to that of normal with regard to substrate specificities and inhibition, except in case of acute and chronic granulocytic leukaemia. The evaluation of these data and its use in diagnosis has to be considered. The results of Lyons et al (20) appeared to be consistent with the above findings with regard to that of heat inactivation and $L$-phenylalanine inhibition. However, Bottomley et al (11) observed that $L$-phenylalanine inhibited the enzyme from normal, chronic granulocytic leukaemia, and reactive granulocytosis in an uncompetitive manner. They suggested that the enzyme may belong to the intestinal and placental phosphatases, since inhibition of intestinal phosphatase by $L$-phenylalanine has been reported by several authors (21-24), and inhibition of human placental phosphatase by the same agent was reported by Fishman et al (22). However, in the present study, more comparative studies, including the use of various substrates and the effect of different inhibitors, showed that the leucocyte alkaline phosphatase does not belong to either the placental or intestinal alkaline phosphatases.

The data presented on the affinity of serum alkaline phosphatase and leucocyte alkaline phosphatase for $\beta$-glycerophosphate and $p$-nitrophenylphosphate, showed that serum alkaline phosphatase is different from that of the leucocyte enzyme. Also it suggested that the high serum alkaline phosphatase in pregnancy is not of leucocyte origin.

Studies on the electrophoretic pattern of leucocyte alkaline phosphatase in normal individuals by Rosenblum \& Petzold (19) revealed one single band. Lyons et al (20) observed three enzyme bands, but occasionally detected 2 or 3 bands simultaneously in their cases. However, they suggested that the variable electrophoretic mobility does not establish the existence of multiple forms of the enzyme, since an apparent isoenzyme may result from artifacts such as molecular aggregation or depolymerization, or when an enzyme binds to a carrier molecule.

Robinson et al $(4,25)$ reported a distinguished leukaemic pattern of electrophoretic mobility of leucocyte alkaline phosphatase in chronic granulocytic leukaemia. Other investigators (26-27) observed that the distribution of leucocyte alkaline phosphatase isoenzyme in chronic granulocytic leukaemia corresponded to that of normal cases.

Bottomley et al (11) reported that similar amounts of enzyme protein could show different enzyme activity. Thus, the enzyme from chronic granulocytic leukaemia had low specific activity, the enzyme from normal leucocytes had intermediate specific activity, and the enzyme from patients with reactive granulocytosis had a very high specific activity. The authors suggested that this could be related to an increase or decrease of active sites on the enzyme molecule, resulting in marked changes in the specific activity of the enzyme molecule.

Rosenblum \& Petzold (19) also could not detect any qualitative difference between the leucocyte alkaline phosphatase in normals, patients with chronic granulocytic leukaemia, and polycythemic patients with regard to molecular weight, inhibition studies, electrophoretic pattern or immunologic characterization. The authors suggested a quantitative difference that could be the responsible factor for the fluctuations in the enzyme specific activity.

From the above study, it can be concluded that there seems to be only one leucocy te alkaline phosphatase enzyme which is probably subjected to the physiological status and/or environment of the individual. In emergency situations, such as severe leucocy tosis, a rapid turnover occurs, resulting in an increased rate of production of granulocytes, associated with an immediate release of a population of newly-formed granulocytes which contain alkaline phosphatase enzyme that may differ in its physical properties from that present in the mature granulocytes.

\section{References}

1. Wachstein, M. (1946), J. Lab. Clin. Med., 31, 1-17.

2. Valentine, W. N. \& Beck, W. S. (1951), Blood, 38, 39-55.

3. Trubowitz; S., Feldman, D., Benante, C. \& Kirmạn, D. (1957), Proc. Soc. Exp. Biol. Med., 95, 35-38.

4. Robinson, J. C., Pierce, J. E. \& Goldstein, D. P. (1965), Science, $150,58-60$.

5. McCoy, E. E:, Park, J. \& England, J. (1965), Clin. Chim. Acta, 12, 453-461.

6. Trubowitz, S. \& Miller, W. L. (1966), Proc. Soc. Exp. Biol. Med. 123, 187-188.

7. Baxter, M. F. \& Reinfrank, R. F. (1971), Blood 37, $512-518$.

8. Berg, G., Roorand, U., Witte, S., Götz, H. \& Bressel, D. (1965). Clin. Chim. Acta 12, 282-291.

9. Weaver, D. D. \& Lyons, R. B. (1968), Lancet, $I, 1196-1197$.

10. Peacock, A. C., Brecher, G. \& Highsmith, E. M. (1958), Amer. J. Clin. Pathol. 29, 80-85.

11. Bottomley, R. H., Lovig, C. A., Holt, R. \& Griffin, M. J. (1969), Cancer Research 29, 1866-1874.

12. Fiske, C. H. \& Subbarow, Y. (1925), J. Biol. Chem. 66, $375-400$.

13. Gornall, A. G., Baradawill, C. J. \& David, M. M. (1949), J. Biol. Chem. 177, 751.

14. Hayhoe, F. G. J. (1960), Leukaemia, Research and Clinical Practice. (J. \& A. Churchill Ltd. London).

15. Hindawy, D. S., El-Aaser, A. A., Hammouda, F. \& Mohieddin, O. (1976), Egypt. J. Haematol. (under publication).

16. Meislin, A. G., Lee, S. L. \& Wasserman, L. R. (1959), Cancer 12, 760-766.

17. Park, J. K. (1970), J. Clin. Pathol. 23, 590-593. 
18. Kaplow, L. S. (1969), Arch. Pathol. 88, 69.

19. Rosenblum, D. \& Petzold, S. J. (1975), Blood 45, 335-342.

20. Lyons, R. B., Weaver, D. D. \& Beck, J. H. (1968), Ann. N.Y. Acad. Sci. 155, 948-971.

21. Fishman, W. H., Green, S. \& Inglis, N. I. (1962), Biochim. Biophys. Acta 62, 363-375.

22. Fishman, W. H., Green, S. \& Inglis, N. I. (1963), Nature 198, 685-686.

23. Ghosh, N. K. \& Fishman, W. H. (1966), J. Biol. Chem. 241, 2516-2522.
24. Êl-Aãser, A. A., Reid, E. \& Stevenson, D. E. (1972), HoppeSeyler's Z. Physiol. Chem. 353, 667-673.

25. Robinson, J. C., Pierce, J. E., Goldstein, D. P. \& Rosse, W. R. (1966), L Lancet $I I, 805$.

26. Rosnẹ̀, F. \& Lee, S. L. (1972), J. Lab. Clin. Med. 79, 228-239.

27. Peterlik, M., Pietschmann, H. \& Vormittag, W. (1970), Folia Hàematoloğica 93, 24-34.

Dr. A. A. El-Aaser, Ph. D. Prof. Cell Chem.

Cancer Institute

Kasr El-Aini Street

Cairo, Egypt 